\title{
Archaeological Survey for the Proposed Seton Home Campus Expansion, City of San Antonio, Bexar County, Texas
}

Richard B. Mahoney

Follow this and additional works at: https://scholarworks.sfasu.edu/ita

Part of the American Material Culture Commons, Archaeological Anthropology Commons, Environmental Studies Commons, Other American Studies Commons, Other Arts and Humanities Commons, Other History of Art, Architecture, and Archaeology Commons, and the United States History Commons

Tell us how this article helped you.

This Article is brought to you for free and open access by the Center for Regional Heritage Research at SFA ScholarWorks. It has been accepted for inclusion in Index of Texas Archaeology: Open Access Gray Literature from the Lone Star State by an authorized editor of SFA ScholarWorks. For more information, please contact cdsscholarworks@sfasu.edu. 


\section{Archaeological Survey for the Proposed Seton Home Campus Expansion, City of}

San Antonio, Bexar County, Texas

\section{Creative Commons License}

\section{(c) (1) (8)}

This work is licensed under a Creative Commons Attribution-NonCommercial 4.0 International License 


\title{
Archaeological Survey for the Proposed Seton Home Campus Expansion, City of San Antonio, Bexar County, Texas
}

\author{
Richard B. Mahoney
}

Center for Archaeological Research

The University of Texas at San Antonio

Archaeological Survey Report, No. 343

(C)2004

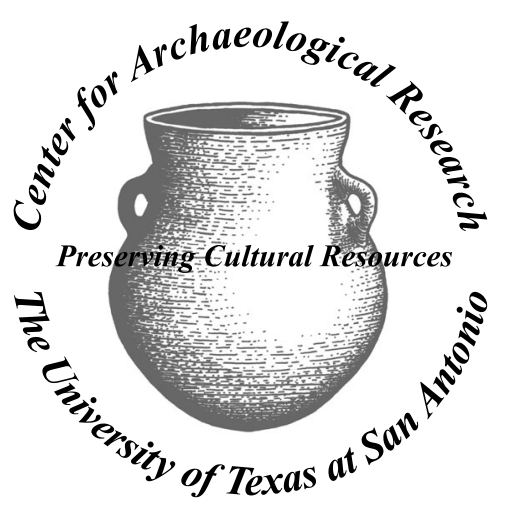




\title{
Archaeological Survey for the Proposed Seton Home Campus Expansion, City of San Antonio, Bexar County, Texas
}

\author{
Richard B. Mahoney
}

Steve A. Tomka

Principal Investigator

Prepared for:

Seton Home

1115 Mission Road

San Antonio, Texas

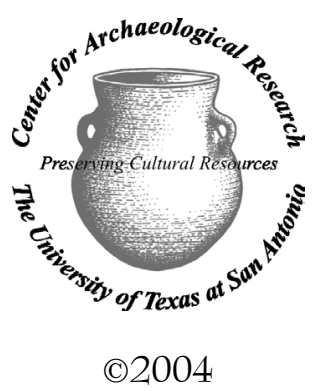

Prepared by:

Center for Archaeological Research The University of Texas at San Antonio Archaeological Survey Report, No. 343 
A list of publications offered by the Center for Archaeological Research is available. Call (210) 458-4378; write to the Center for Archaeological Research, The University of Texas at San Antonio, 6900 N. Loop 1604 W., San Antonio, Texas 78249-0658; e-mail to car@lonestar.utsa.edu; or visit CAR's web site at http://car.utsa.edu. 


\section{Abstract:}

During November 2003, the Center for Archaeological Research of The University of Texas at San Antonio conducted an archaeological survey for a proposed 9.3-acre development at the Seton Home property in the City of San Antonio, Bexar County, Texas. The Phase I survey consisted of a 100 percent pedestrian survey and the excavation of 24 shovel tests. A portion of previously recorded site 41BX1570 was investigated with six shovel tests, delimiting the southern boundary of the site. Moderate amounts of burned limestone, burned chert, and lithic debitage comprised the prehistoric artifact assemblage. During current and previous investigations, several modern artifacts were encountered with the prehistoric deposits throughout the vertical column to the terminal excavation depth of 70 centimeters below surface. The presence of these modern artifacts, in concert with evidence of significant historic subsurface disturbance, has provided adequate data to determine this site ineligible for inclusion in the National Register of Historic Places or for listing as a State Archeological Landmark.

Under the Scope of Work for the current project, archaeological monitoring of a subsurface utility line is specified. Location of the line is proposed at or near the northern property boundary separating Seton Home and St. Peter-St. Joseph Children's Home. Site 41BX1570 will be bisected by the utility line, regardless of alternative placement in the general vicinity. The excavation of the utility trench and the monitoring of these excavations will occur during the spring of 2004. The results of this monitoring will be reported within a separate letter report. However, this report is produced to summarize the results of the pedestrian survey and serves to provide for clearance of cultural resources only in the remainder of the project area. It is recommended that construction be allowed to proceed outside of the proposed utility corridor. 


\section{Table of Contents:}

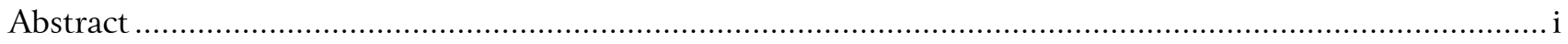

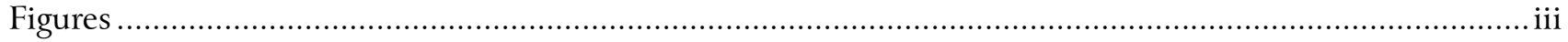

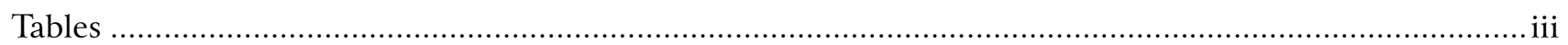

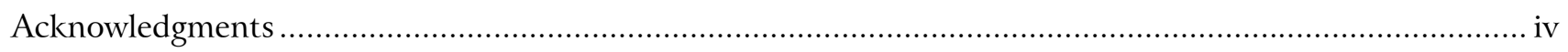

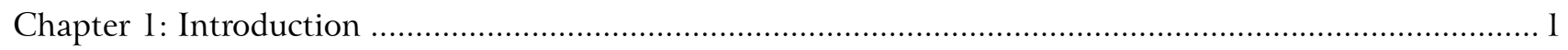

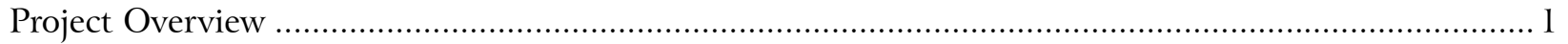

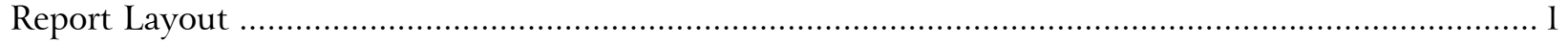

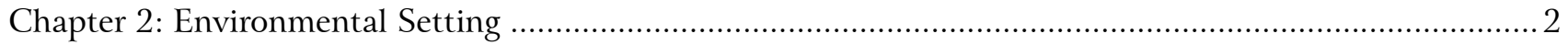

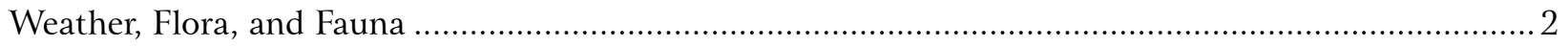

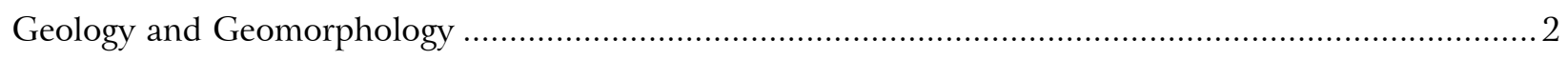

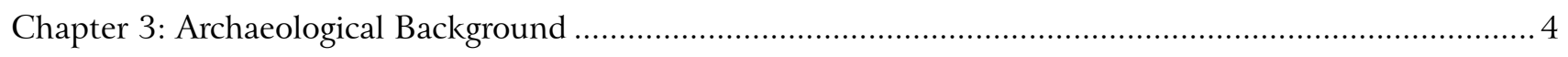

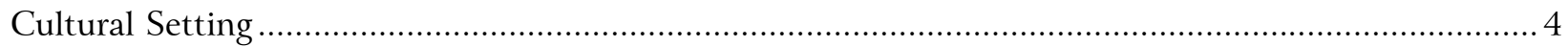

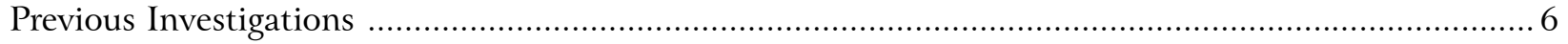

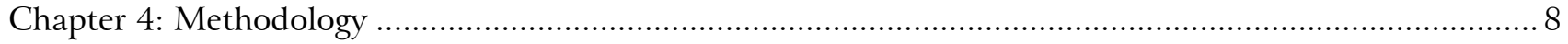

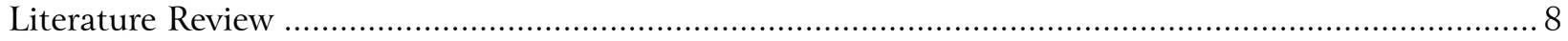

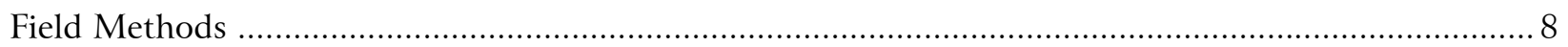

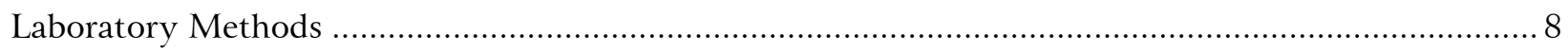

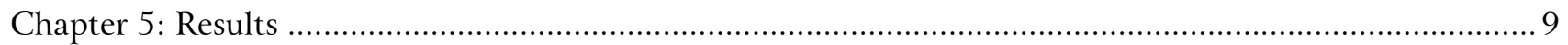

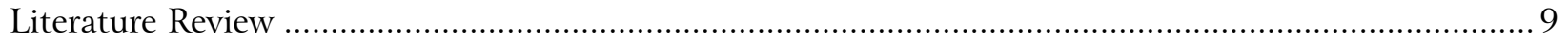

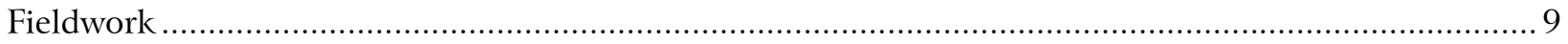

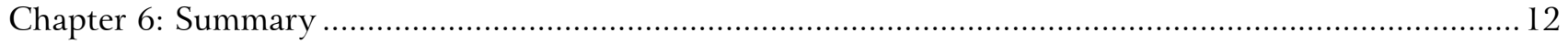

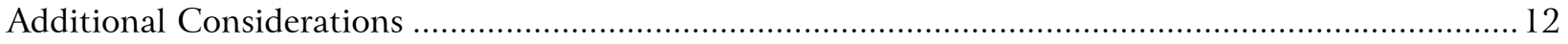

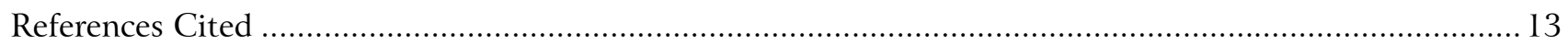




\section{Figures:}

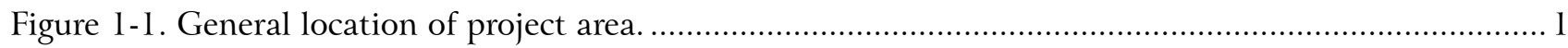

Figure 2-1. Project area in relationship to Natural Regions of Texas. .................................................

Figure 2-2. Map of the San Antonio River in proximity to the project area. ............................................ 3

Figure 5-1. Portion of Tobin ${ }^{\circledR}$ aerial photograph of the campus during the late 1960s.............................9

Figure 5-2. Distribution of shovel tests excavated during November 2003........................................... 10

\section{Tables:}

Table 5-1. Artifact Recovery from Shovel Tests S7 and R6 at 41BX1570 


\section{Acknowledgments:}

Several individuals have contributed to the successful completion of this project. The Center for Archaeological Research (CAR) would like to thank Marmon Mok Architects for facilitating CAR throughout the project. Ms. Kathy Mittler and Mary Curlee of Seton Home were also helpful with regard to scheduling the field efforts. The field crew consisted of Stacy Wagner, Jason Weston, and the author. Bryant Saner, under direction of Marybeth Tomka, CAR Laboratory Director, conducted laboratory processing and inventory. Anne Fox and Waynne Cox, CAR Staff Archaeologists, contributed valuable information on the local archaeology of the project area. Steve Tomka, CAR Director, provided technical advice. Bruce Moses and Richard Young, CAR draftsmen, produced the figures in this report. Johanna Hunziker, CAR editor, produced the final version of this report. 


\section{Chapter 1: Introduction}

The Center for Archaeological Research (CAR) of The University of Texas at San Antonio was contracted by Seton Home of San Antonio to conduct an archaeological survey of an approximately 9.3 -acre tract proposed for development in Bexar County, Texas (Figure 1-1). Subsurface disturbance as a result of proposed development will impact an area of only 1.85 acres $(0.75$ ha), however, the entirety of the 9.3 acres was subject to survey as per the request of the client. The purpose of the survey was to locate and identify any cultural resources that may be impacted by this proposed development. The survey was performed by CAR staff during November 2003.

\section{Report Layout}

This report is comprised of six chapters. Following this introductory chapter, Chapter 2 presents the environmental setting of the project area. Chapter 3 reviews the archaeological background for the area, including the cultural setting and previous archaeological investigations. Chapter 4 discusses the methodology employed for the testing, specifically the background literature review, and field and laboratory methods. Chapter 5 details the outcome of the archaeological fieldwork. Chapter 6 summarizes the current project and offers management recommendations.

The survey was performed under the guidelines of the Historic Preservation and Design Section (Article 6) of the Unified Development Code, Department of Planning, Historic Preservation Office, City of San Antonio. Steve Tomka, CAR Director, served as Principal Investigator.

\section{Project Overview}

The proposed Seton Home project is located southwest of Mission Road, across from Mission Concepción. The project area is bound to the south and west by unimproved and improved lands bordering the channelized San Antonio River; to the northwest by St. PeterSt. Joseph Children's Home; and to the northeast by Mission Road.

Proposed development in the project area consists of various construction tasks ranging from parking areas to dormitory buildings to utility lines. Subsurface impact as a result of these developments will vary from $45 \mathrm{~cm}(18$

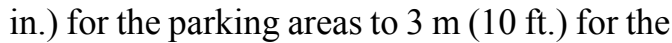
utility lines.

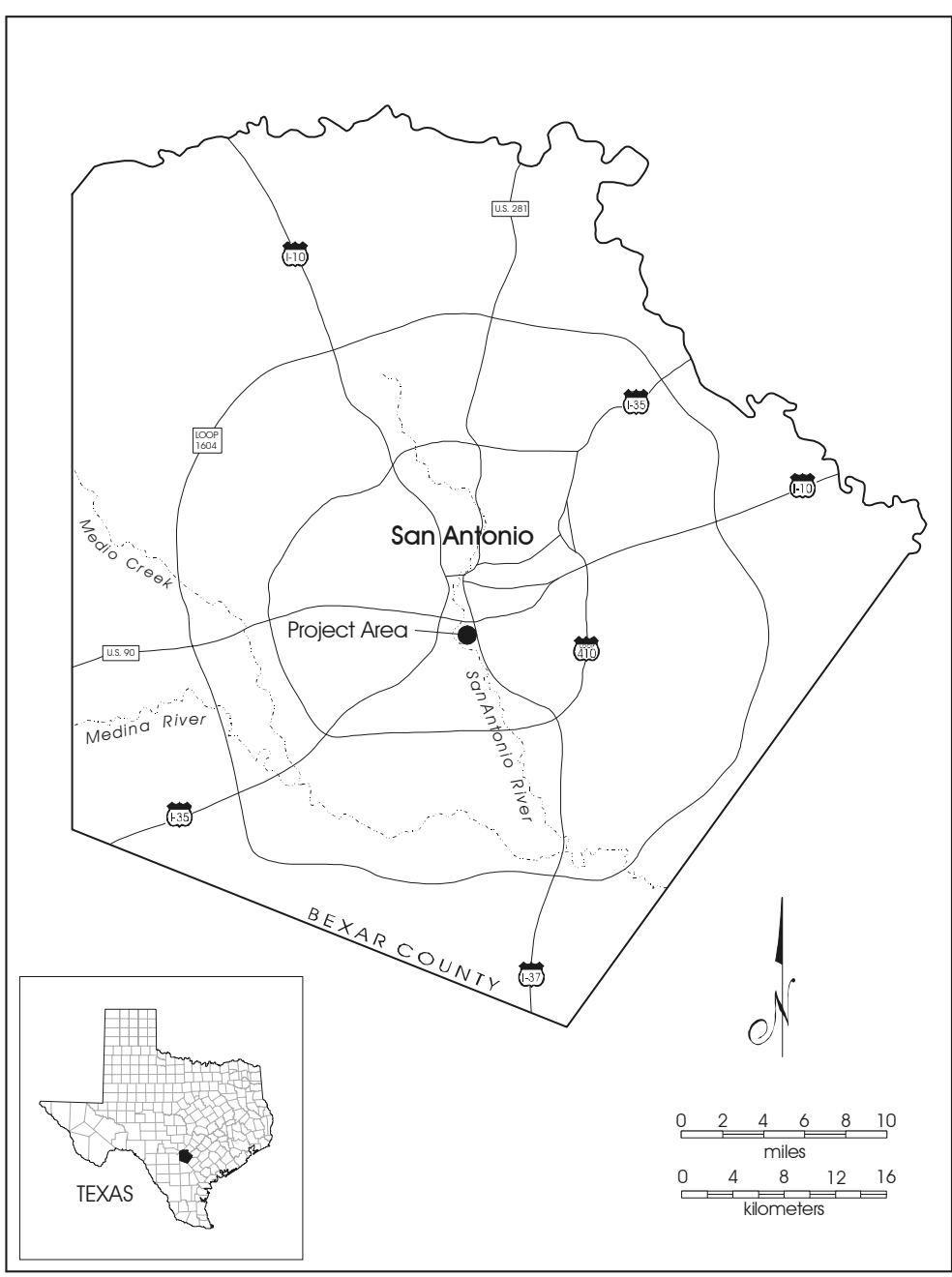

Figure 1-1. General location of project area. 


\section{Chapter 2: Environmental Setting}

As the environment of Bexar County is quite diverse, a summary of the environment specific to the immediate project area is provided to furnish a background for understanding prehistoric human adaptations to the South Texas Brush Country, Blackland Prairie, and Edwards Plateau vegetation regions found in the vicinity of the project area (Figure 2-1).

The San Antonio River forms at the confluence of Olmos Creek with natural springs north of downtown San Antonio. Olmos Creek, in turn, heads in the Edwards Plateau region of northern Bexar County, flows through limestone bedrock formations across the Balcones Escarpment, reaching the Blackland Prairie near the confluence with the San Antonio River. The project area is situated atop an upper terrace of the San Antonio River. The river has since been channelized in this portion of its course (Figure 2-2), with the extant channel now some $250 \mathrm{~m}$ ( $825 \mathrm{ft}$.) west of its pre-channelized meander.
The northern boundary of this region is formed by the Balcones Escarpment.

Blair (1950:104) identifies the fauna of the region as diverse with numerous species of mammals, reptiles, and amphibians. Prior to urbanization, the riparian zone along the San Antonio River would have afforded a resourcerich environment for such mammals as white-tailed deer, rabbit, squirrel, raccoon, opossum, skunk, and various rodents. Similarly, reptiles, amphibians, fish, and bivalves would likely have favored such a riparian area.

\section{Geology and Geomorphology}

The geology of Bexar County consists primarily of Mesozoic formations beginning with the Cretaceous Trinity Group in the northwest and continuing with the Eocene Claiborne Group in the extreme southeast. Quaternary undivided deposits are present in the central

\section{Weather, Flora, and Fauna}

Bexar County has a subtropical climate, with warm winters and hot summers. The average winter temperature is $58^{\circ} \mathrm{F}\left(14^{\circ} \mathrm{C}\right)$ and the average summer temperature is $80^{\circ} \mathrm{F}\left(27^{\circ} \mathrm{C}\right)$. The growing season averages 245 days a year in the northern half of the county and 275 days a year in the southern half of the county. The prevailing winds are light ( 8 knots) and predominantly flow from the southeast. The average annual precipitation is 31 inches $(79 \mathrm{~cm})$, with rainfall evenly distributed throughout the year (Taylor et al. 1991:118). Atlantic hurricanes occasionally affect the county, causing high winds and sporadic, heavy rainfall. The project area lies along the northern boundary of the Tamaulipan biotic region of South Texas, a region characterized by thorny brush, including mesquite, acacia, white brush, and prickly pear (Blair 1950:103).

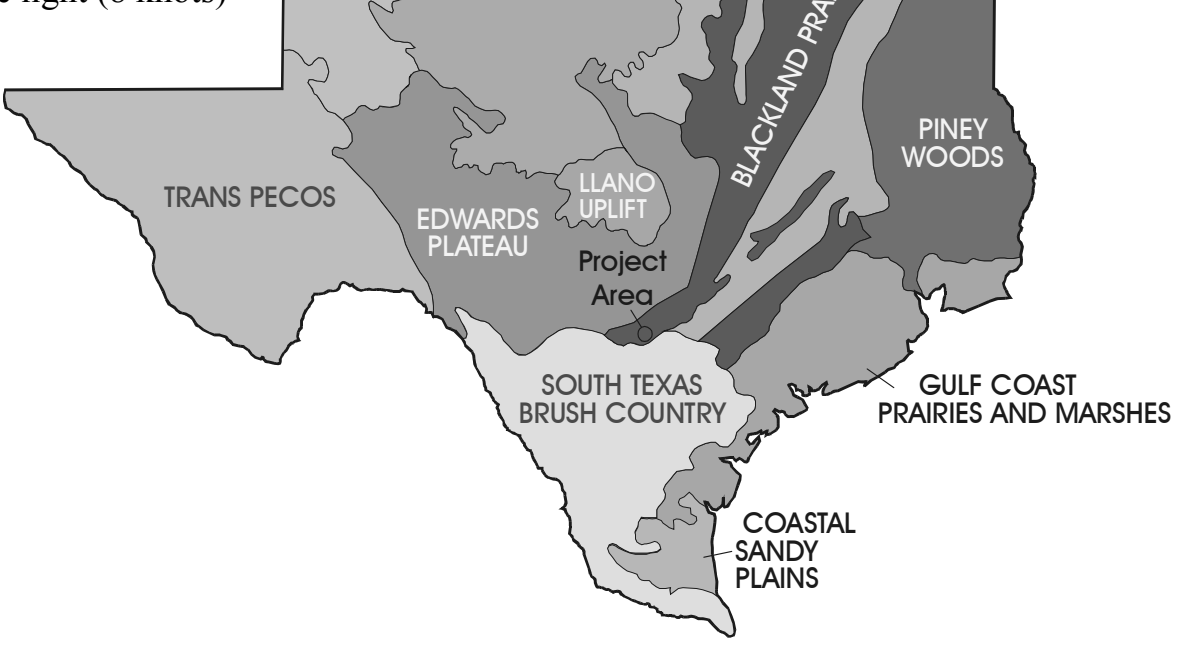

Figure 2-1. Project area in relationship to Natural Regions of Texas. 


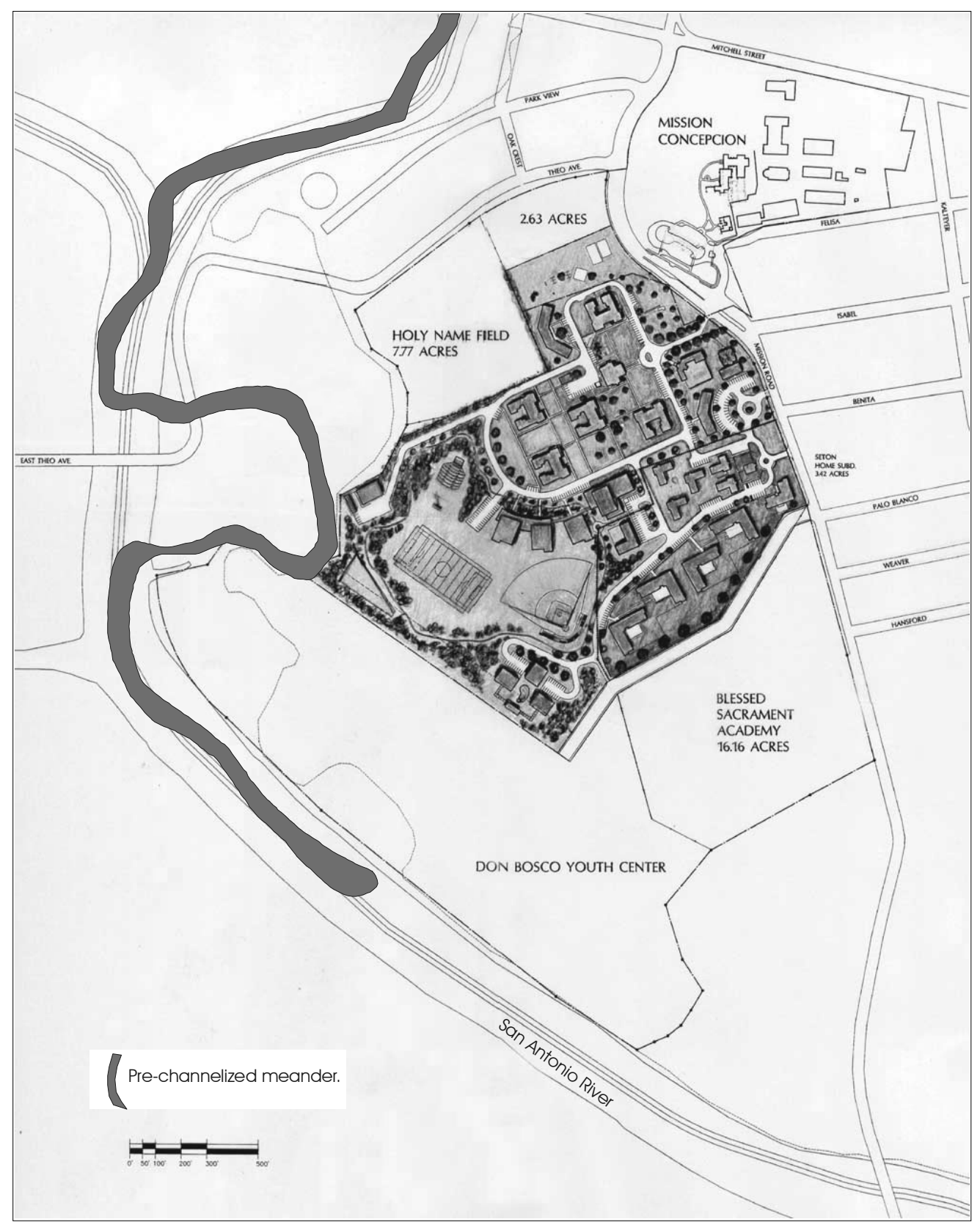

Figure 2-2. Map of the San Antonio River in proximity to the project area. Note the natural and channelized meanders.

portion of the county, underlying the southern part of the City of San Antonio. Located within these Quaternary fluviatile deposits, the project area is situated atop the Holocene alluvial deposits of the San Antonio River.

The project area is within the West Gulf Coastal Plain section of the Coastal Plains physiographic region (Fenneman 1931). The Venus-Frio-Trinity Association of deep, calcareous soils on bottomlands and terraces comprises the area of current investigations (Taylor et al. 1991). Specifically, the soil is delineated as Venus clay loam (Taylor et al. 1991:Map Sheet 63), with a loam to clay loam texture. 


\section{Chapter 3: Archaeological Background}

A brief overview of the prehistoric cultural context of South Texas relative to the project area and a synopsis of previous archaeological investigations conducted in the immediate vicinity of the project area is presented in this chapter. These summaries are based, in part, on more comprehensive reviews of cultural chronologies and archaeological investigations found in Black (1989), Hester (1995), Tomka et al. (1997), and Vierra (1998).

\section{Cultural Setting}

The chronological sequence discussed below is based on Black (1989), Collins (1995), and Hester (1995). Most attempts to develop a culture history for South Texas have depended almost entirely on information from Central Texas, Lower Pecos, and Gulf Coast sites. This practice has been, in the past, considered acceptable because of the similarity of many artifact assemblages, especially projectile points, across these regions. An additional contributing factor was the lack of deeply stratified South Texas sites needed for the development of a regional chronological sequence.

Hester (1995:429) notes that most South Texas sites are open campsites, often found to be completely superficial or having very shallow artifact-bearing zones which were either very stable over thousands of years or are the result of serious erosion and deflation. Many of these sites are "occupation zones," i.e., long, narrow stretches along creek or river banks with a thin scatter of artifacts containing a wide variety of temporal diagnostics in a confusing horizontal array. While the formation of such zones is, in itself, a distinctive regional trait, the analysis of material from such sites is difficult (Hester 1995:430). The lack of buried, undisturbed, stratified sites in the region has severely limited the development of a regional chronology.

\section{Paleoindian ( $11,200-8000$ BP $)$}

The early Paleoindian period, characterized by Clovis and Folsom points, is not well understood throughout South Texas. An early Paleoindian presence in South Texas is represented by rare finds of Clovis and Folsom points (Hall 1984; Hester 1995). Bifacial Clear Fork tools and finely flaked end scrapers are often associated with Paleoindian points (Black 1989). Many of these early Paleoindian points are found as isolated artifacts or in association with later materials (Hall 1984).

Paleoindian groups are assumed to have been small and highly mobile, focusing primarily on the exploitation of large game. However, recent research on Paleoindian materials from the Wilson-Leonard site in Central Texas (Collins 1998), and new perspectives on Paleoindian adaptations (e.g., Tankersley and Isaac 1990) suggest that the diet of these early groups may have been much broader than previously assumed. A variety of small game may have served as common sources of animal protein, at least on a seasonal basis. Similarly, the distance traveled by a group may have been, at least in some cases, much smaller than previously assumed (Tankersley and Isaac 1990).

While isolated Paleoindian projectile points are found on a variety of landforms (Hester 1995), most sites with Paleoindian materials are found on high terraces, valley margins, and upland locations (Black 1989). This pattern is similar to Paleoindian site distribution in other parts of the country, in that sites of this time period tend to be found on landforms that provide good overviews of the surrounding landscape, are centered on critical resource zones, or are found in high-productivity drainage areas (Tankersley and Isaac 1990). The existence of deeply buried Paleoindian components in alluvial contexts (Berger Bluff [41GD40]; Brown 1987) does indicate that some caution should be exercised in excluding valley bottom settings from the Paleoindian land-use system.

\section{Early Archaic (8000-5000 BP)}

Sollberger and Hester (1972) have suggested that the shift from the Paleoindian to an Archaic tradition was gradual, and spanned nearly 3,000 years (8000-5500 BP) in central and southern Texas. Hester (1995:436), using only projectile point morphology, defined two wide-spread horizons for the Rio Grande Plains. These are the Early Corner Notched (8000-5500 BP) marked by Uvalde, Martindale, and Baker forms; and the Early Basal Notched (5500-5000 BP) characterized by Bell and 
Andice points. He believes that the distinctive Guadalupe biface may be associated with the former.

Sites are usually found on terraces near water or on the hilly areas overlooking valleys (Hester 1995:439). Both in the Chaparrosa Ranch and East Chacon areas of western South Texas, Early Archaic sites tend to be found in "water-proximate" areas, such as high terraces overlooking major creeks (see Hester 1978; McGraw and Knepper 1983). Almost no direct evidence of subsistence is available, largely because preservation of faunal material and plant macro- and micro-remains is poor in the Rio Grande Plains (Hester 1995:439).

\section{Middle Archaic (5000-2400 BP)}

Diagnostic artifacts for this period include Pedernales, Langtry, Kinney, and Bulverde points. Tortugas, Morhiss, and Lange points appear late in the period, after 2950 BP (Black 1989). In addition, distally beveled tools, tubular pipes, and triangular bifaces, which persist throughout the Archaic, are common (Black 1989; Hester 1995). Although not as numerous or as large as those found in Central Texas, accumulations of burned rock containing artifacts datable to this interval are found in the northern parts of the region. Manos and metates are very common from this period, and into the Late Archaic. In general, however, the evidence points to less intensive plant resource utilization than is seen in Central Texas.

During the Middle Archaic, open campsites occur inland on knolls and bluffs along stream channels and tributaries, and along estuary bays in the Coastal Bend region (Black 1989; Story 1985). In the later part of the Middle Archaic period, sites are also commonly located on floodplains, low terraces, and natural levees, in addition to the upland settings (Hester 1995).

Subsistence remains from Middle Archaic sites indicate the use of nuts and mesquite beans, acacia, hackberry, and oak (Hall et al. 1986). Freshwater mussels, land snails, deer, and small mammal remains are common, as are littoral resources along the coast (Black 1989). Sites with large accumulations of burned rock are common in Central Texas (Black 1989; Hester 1995). Plant remains found in association with burned rock accumulations indicate that these middens were formed during the processing of plant resources. This indicates an increased reliance on plant foods requiring intensive processing (Black 1989).

The first large cemeteries appear during the later part of the Middle Archaic, at sites like Loma Sandia (Taylor and Highley 1995) and Morhiss (Campbell 1976). It has been suggested that these cemeteries reflect an increase in population and/or territorial restriction (Black 1989; Hester 1995; Story 1985).

\section{Late Archaic (ca. 2400-1 150 BP)}

The Late Archaic in South Texas is characterized by the presence of Shumla, Ensor, Montell, and Marcos points and Olmos bifaces (Hester 1995:441). In and near Webb County, Desmuke, Matamoros, and Catan points are found. Large (15-20 cm long), thin, triangular bifaces made of non-local cherts are another Late Archaic tool found in the Rio Grande Plains area (Hester 1995:442). Corner-tang bifaces and small distally beveled tools called Nueces scrapers are common (Black 1989). Olmos bifaces, small triangular gouge-like tools, are common in South Texas (Hester 1995). Manos and grinding slabs also are common in South Texas during this period.

Late Archaic sites are usually located near modern stream channels and occur in all topographic settings (Black 1989; Hester 1995). Sloughs or oxbow lake margins were also preferred site locations (Kelly 1983; McGraw and Knepper 1983). Subsistence was broadly based, with a wide range of animal species present in sites, along with large amounts of freshwater mussel shell in some sites (Hester 1995:442). There seems to have been a greater reliance on a broad spectrum of plant resources, with small animals (e.g., rodents, rabbits, turtles, fish, lizards, and snakes) and land snails also of importance (Black 1989). While there appears to be a decline in the accumulation of large burned rock deposits in Central Texas (Black 1989), extensive deposits of fire-cracked rocks continue to occur in Late Archaic sites in South Texas (Hester 1995).

There is a continued use of large cemeteries first seen in the Middle Archaic. Examples include the Ernest Witte, Leonard K., and Morhiss sites, as well as many others (Perttula 1997; Taylor and Highley 1995). There is an increase in the number and variety of grave inclusions found in the later Archaic burials at these cemeteries (Black 1989; Hall 1981, 1984; Hester 1995). 


\section{Late Prehistoric (ca. 1150-350 BP)}

At about 1150 BP there is a distinctive shift in artifact assemblages across Central and South Texas: the use of the atlatl and dart points is replaced by the bow and arrow. This early period of the Late Prehistoric in Central Texas is termed the Austin Phase (1150-600 BP). During this period, the first evidence of bone-tempered pottery is found in association with expanding stem arrow points. Edwards, Granbury, and Scallorn arrow points are commonly found on early Late Prehistoric sites; the latter type, in particular, is found over most of the state. Edwards points have been found largely in the southern portion of the Edwards Plateau, although they are occasionally seen outside this area (Prewitt 1995:102). The relationship of this point to Scallorn points and other Austin Phase arrow points is still being addressed (Hester 1995:443).

At about $600 \mathrm{BP}$, arrow point forms shift from expanding stem types to contracting stem types such as Perdiz and Cliffton (Black 1989). This latter part of the Late Prehistoric in Central and South Texas is termed the Toyah Phase. It is characterized by Perdiz and Cliffton arrow points, often found in association with bison bones or kill sites, beveled bifaces, drills, small scrapers, a flakeblade lithic technology, and bone-tempered Leon Plain ceramics (Hall 1981; Prewitt 1981; Skelton 1977). Tools made from bison bone are also common. The sharp increase in frequency of bison bone in Toyah sites is distinctive, suggesting that the importance of hunting large game increased, though small mammals, riverine species, mussels, and land snails continue to be important contributions to the diet (Hall 1981; Hester and Hill 1975; Prewitt 1981; Skelton 1977).

\section{Previous Investigations}

Due to the project area's proximity to the site of Mission Concepción, numerous research projects have been conducted in the general vicinity. During 1971 and 1972, the Texas State Historical Survey Committee (now the Texas Historical Commission [THC]) sponsored the first archaeological project at the mission. The purpose was to examine the foundations of the church walls to determine if the deterioration of the lower walls of the church was due to problems with the foundation. The second part of the project was to relocate the granary and the west wall of the Colonial-period compound (Scurlock and Fox 1977:1). The project determined that the foundation of the church appeared dry and solid, and located a series of wall remnants. Numerous Colonial, as well as nineteenth- and twentieth-century middens were documented. The possible remains of acequias were encountered in at least two areas (Scurlock and Fox 1977:43, Figure 13). Much of the south and west wall areas were found to be seriously disturbed by bulldozing in the 1950s.

Beginning in December 1980, with a second field phase concluding in June of the following year, CAR continued the search for the original walls of the mission. This report has only recently been published (Ivey and Fox 1999). These excavations confirmed that the southern part of the west wall and most of the south wall were badly disturbed, while the east and north wall foundations, along with remains of associated rooms, were relatively undisturbed (Ivey and Fox 1999:9, Figure 4). This project also located some of the foundations of the original convento, built before the current building (Ivey and Fox 1999:15). The remains of two sections of acequia were found, one just north of the church, and the other near the south wall in the vicinity of the section discovered by Scurlock and Fox (1977). Portions of the east and north walls also were recorded.

In 1986, CAR archaeologists tested an area south of the church in order to determine the best route for a drainage pipe needed to prevent occasional flooding of the convento. Two excavation blocks (one $12 \mathrm{~m}^{2}$ and the other $4 \mathrm{~m}^{2}$ ) were placed south of the convento. These excavations showed that although the remains of several walls were present, the artifacts recovered indicated that considerable disturbance had taken place in the area (Fox 1988:20).

Plans to realign Mission Road outside the mission compound led to further excavations by CAR in 1987. This project was intended to locate any significant features, especially acequias, that might be impacted when the new Mission Road was constructed west and outside the original mission compound (Labadie 1989). 
Three backhoe trenches and a series of 11 test trenches located the remains of an acequia, but otherwise showed that the area west of the mission had been seriously disturbed. The alignment of the acequia west of the mission suggests that it trends slightly northwest of Seton Home and the current, proposed development. CAR personnel also monitored the construction of an electrical conduit trench and a condensation line for an air conditioning system. The electrical conduit trench crossed one wall, presumably part of the foundation of the first convento (Fox 1989).

In 1990, further testing of the area between the old Mission Road and the new realignment located a few remains of the west wall, but otherwise documented extensive disturbance of the west wall area of the mission compound. The presumed location of the northwest corner of the mission compound had been disturbed by utility trenches (Brown et al. 1994). An additional test trench was later excavated to locate the north wall near the northwest corner. Extrapolation from the wall found in this trench confirmed that the northwest corner of the church had been destroyed (Fox 1992).

During 1998 and 1999, CAR investigated a large number of animal bones that were unearthed by a construction crew. The feature was determined to be a section of an acequia that had been filled with construction debris and trash, including large numbers of animal bones, during the Spanish Colonial period (Meissner 2001). Subsequent monitoring of other underground utility work in the area resulted in the location of a Colonial-period wall, southeast of the mission Visitors' Center, which may have been part of the original south wall of the mission compound.

CAR has conducted archaeological field schools during the 2002 and 2003 field seasons within the known bounds of the mission. These excavations were conducted primarily to further define structural walls associated with the mission proper. Several structural remnants were encountered, and the investigations will continue through the summer of 2004.
Most recently, CAR surveyed portions of the adjoining St. Peter-St. Joseph (St. PJ's) Children's Home (Mahoney 2003). The survey resulted in the recordation of prehistoric site 41BX1570, a portion of which extends onto the northern section of the Seton Home property. 


\section{Chapter 4: Methodology}

This chapter details the various field and laboratory techniques and methods used to investigate the project area. Each general step of the process is presented and includes sections concerning the initial literature review, field methods, and laboratory methods.

\section{Literature Review}

The archaeological research commenced with a comprehensive review of available archaeological reports and databases to identify and characterize all archaeological sites known to occur in the general vicinity of the project area. At least in part, the compilation of the known prehistoric and historic sites within and in the vicinity of the project area is based on the Texas Archeological Sites Atlas, Texas Historic Sites Atlas, and THC map files that contain information on all sites recorded within each county in the state. During the literature and archival review, we also inspected United States Geological Survey (USGS) topographic maps and the USDA Soil Conservation Service's Soil Survey of Bexar County (Taylor et al. 1991). Recent projectspecific aerial photographs were assembled for the delimitation of the project area in an $\mathrm{ArcView}^{\circledR}$ database. This baseline was used to define the precise limits of the project area.

\section{Field Methods}

The survey consisted of a 100 percent pedestrian survey of the proposed project area ( 9.3 acres). A crew of three archaeologists traversed the project area along 30-meter transects. Aerial photographs and hand-held compasses were used to orient crew members along their routes.

For the purpose of this survey, sites are defined as locations having at least five artifacts within a $30 \mathrm{~m}^{2}$ area, or as a location containing a single cultural feature such as a hearth. All other artifacts were classified as isolated occurrences. Shovel tests were conducted in accordance with the Texas Historical Commission archaeological survey standards at an average rate of two (2) shovel tests for every one (1) acre, resulting in a minimum of 19 shovel tests within the project area.
Shovel tests were $30 \mathrm{~cm}$ in diameter and were excavated to a maximum depth of $70 \mathrm{~cm}$ below surface, unless otherwise prevented from reaching this depth. They were excavated in levels not exceeding $10 \mathrm{~cm}$ in thickness. Deposits from these tests were screened through $1 / 4$-inch hardware cloth, all artifacts were collected, and all observations on the shovel tests were recorded on standardized forms. When evidence of cultural activity was encountered in a shovel test, additional shovel tests were excavated to define the extent of the distribution.

\section{Laboratory Methods}

All cultural material recovered was inventoried at the CAR laboratory. All artifacts recovered were identified and analyzed. Processing of artifacts began with washing and sorting into appropriate categories (e.g., debitage, tools). The catalog was entered into an Excel spreadsheet.

All cultural material collected during the survey was prepared in accordance with current state and/or federal regulations. Artifacts processed in the CAR laboratory were stored in archival-quality bags. Acid-free labels were placed in all artifact bags. Each label contains a provenience or corresponding lot number.

Subsequent to proper analyses and/or quantification, artifacts possessing little scientific value were discarded pursuant to Chapter 26.27(g)(2) of the Texas Administrative Code. Artifact classes discarded specific to this project included burned rock, mechanically fractured chert, and snail shell. In all instances, discarded materials were documented and their counts included in this report and curation documentation. Discarded materials were disposed of in a manner consistent with suitable disposal procedures.

Field notes, forms, and drawings were placed in archivally stable folders. Documents and forms were printed on acidfree paper. A copy of the survey report and all computer disks pertaining to the investigations were curated with the field notes and documents. After completion of the project, all cultural material and records were curated at the CAR permanent storage facility. 


\section{Chapter 5: Results}

This chapter presents the results of investigations for the Seton Home project. It is subdivided into sections reporting on the results of the initial literature review and the fieldwork.

\section{Literature Review}

Numerous reports summarizing previous investigations and previously recorded archaeological sites were reviewed to provide a background for the types of cultural material that may be encountered in the project area. In addition, numerous cartographic resources were examined to determine the extent of historic activity within the area.
An undated Tobin ${ }^{\circledR}$ aerial photograph (probably from the late 1960s) depicts the location of the project area prior to original construction (Figure 5-1). Visible on this photo is the vegetation, consisting of open, grassy fields and sparse tree cover.

\section{Fieldwork}

A total of 24 shovel tests was excavated across the 9.3acre project area. Figure 5-2 depicts the distribution of shovel tests across the project area. Of note in the figure is the lack of shovel tests in the southwestern portion of the project area. While the entirety of the project area was subject to pedestrian survey, this low-lying,

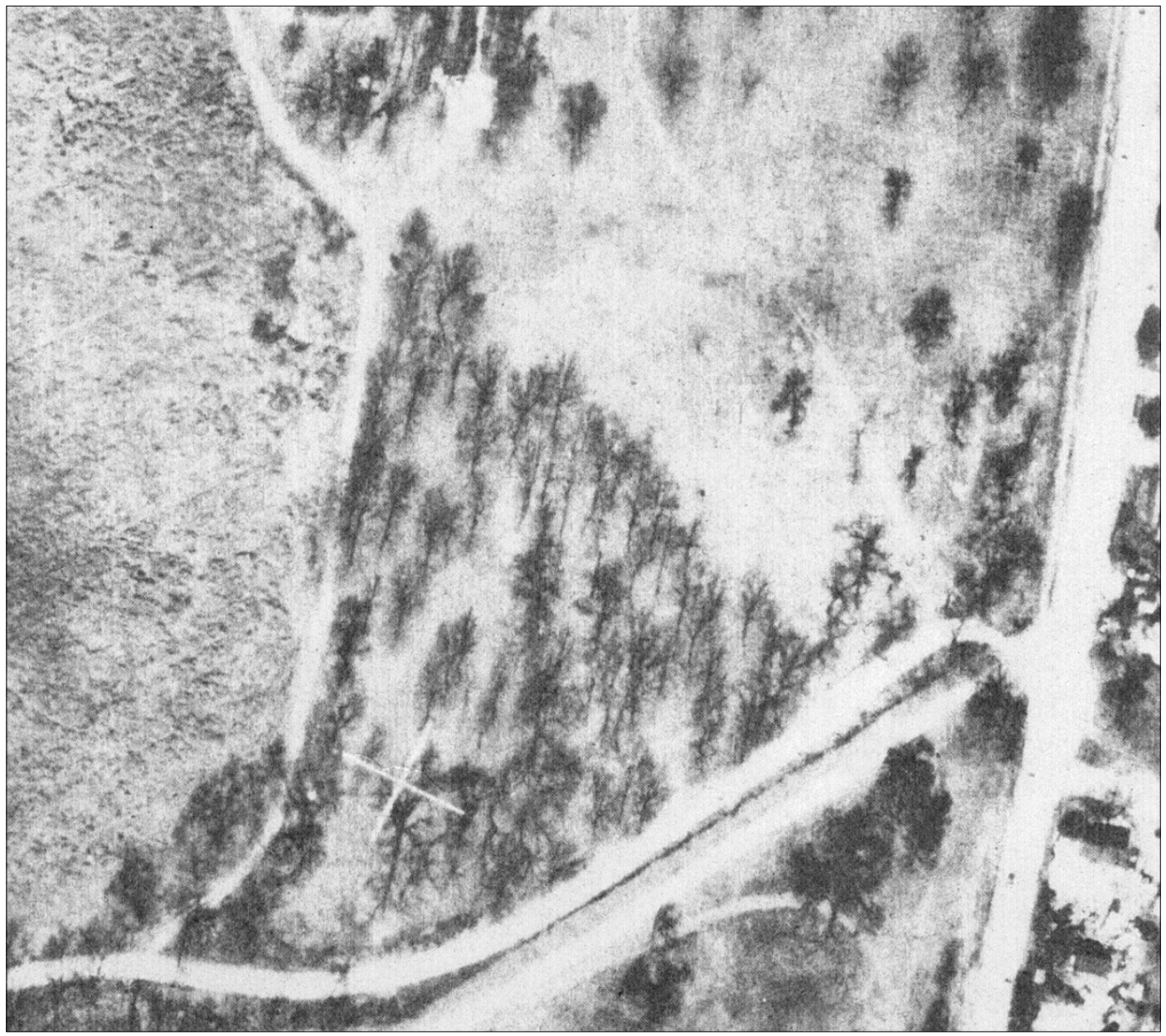

Figure 5-1. Portion of Tobin ${ }^{\circledR}$ aerial photograph of the campus during the late 1960s. Mission Road is to the right. (Map on file at CAR.) 


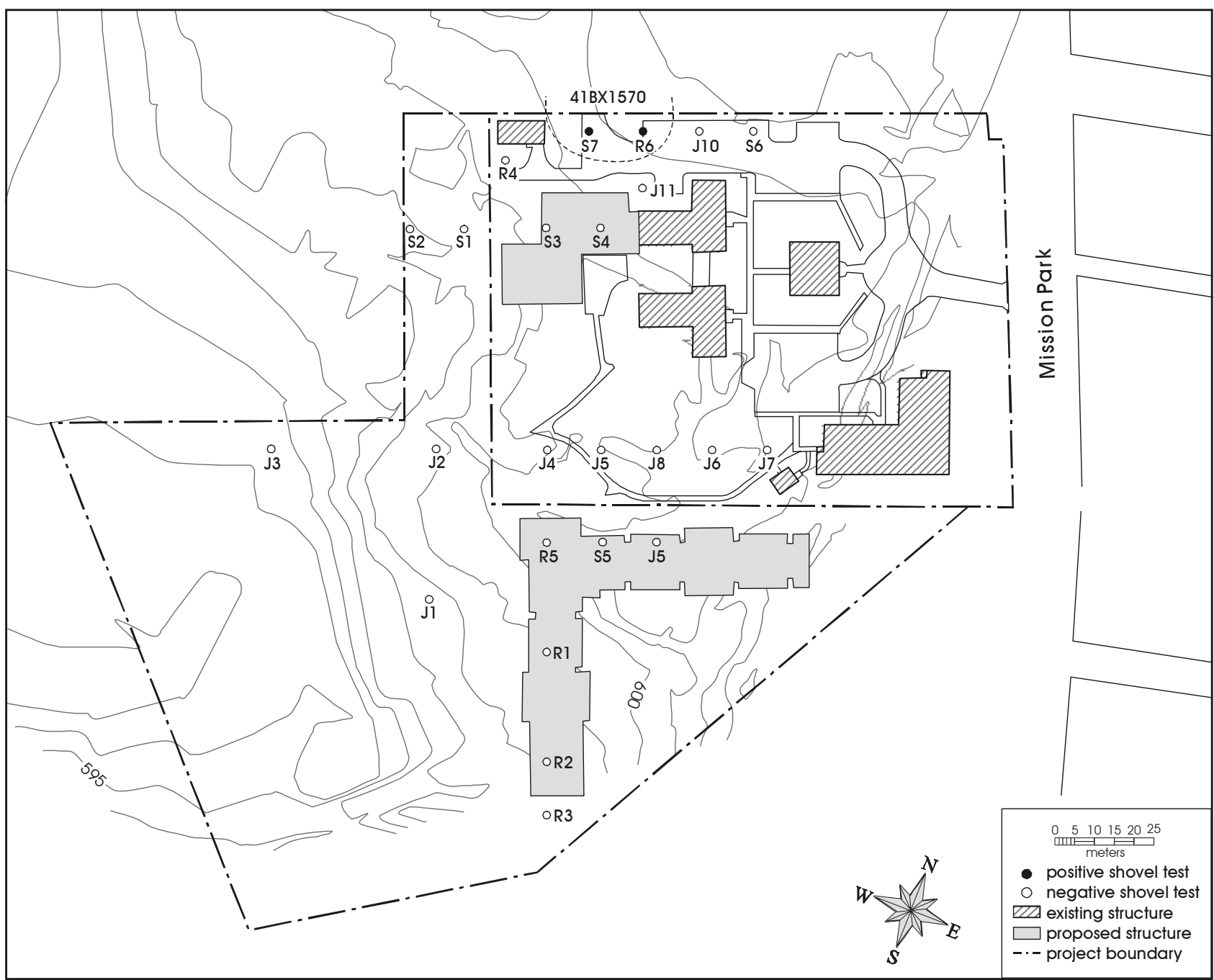

Figure 5-2. Distribution of shovel tests excavated during November 2003.

southwestern portion was not subject to shovel testing. This decision was made based on the presence of standing water in that area during the time of survey. Similarly, current activity areas were not subject to shovel testing. These areas include a sunken volleyball court, picnic table areas, service drives, parking lots, and concrete sidewalks

The remainder of the project area was subject to ample coverage of shovel tests. The rate of shovel tests well exceeds the Minimum Survey Standards for Project Areas of 200 Acres or Less, espoused by the THC. Under these guidelines, the THC proposes a density of two shovel tests per acre (2:1) for project areas of from three to ten acres in size. Excavation of 24 shovel tests for the current project results in a shovel test density to project area size of roughly $2.6: 1$.

A single previously recorded archaeological site, 41BX1570, was encountered and recorded during the field efforts. The site occurs along the northern property boundary separating Seton Home and St. PJ's. Within the St. PJ's property, the site covers an area approximately $60 \mathrm{~m}$ long (east to west) and $45 \mathrm{~m}$ wide (north to south; Mahoney 2003). Within the Seton Home property, two shovel tests (R6 and S7) encountered cultural deposits, widening the site by an additional 15 meters. 
A total of 62 artifacts was recovered from the two positive shovel tests (Table 5-1). Of note in Table 5-1 is that historic artifacts $(n=26)$ were encountered only in Shovel Test (ST) S7. Of these 26 historic artifacts, the majority $(58 \%$; $\mathrm{n}=15)$ occurred at $10-20 \mathrm{~cm}$ below surface (bs). However, it should be noted that eight percent of the historic assemblage occurred at 60-70 cmbs.

The prehistoric artifact assemblage $(n=36)$ recovered from the two positive shovel tests is comprised of lithic debitage $(\mathrm{n}=8)$ and burned limestone $(\mathrm{n}=9)$ and chert $(\mathrm{n}=19)$. ST R6 produced the majority $(92 \%)$ of the prehistoric assemblage, with only three prehistoric artifacts recovered from ST S7. Two of the three prehistoric artifacts from ST S7 were recovered in Level $7(60-70 \mathrm{cmbs})$, while the third was recovered in Level 3 (20-30 cmbs).

Soils encountered in the positive shovel tests included loam to clay loams. In ST R6, limestone gravels were encountered in the upper portion of the profile, with larger limestone gravels and small cobbles occurring in the lower portion of the profile. Solid limestone was encountered at $58 \mathrm{cmbs}$. No indication of significant disturbance was noted in the ST R6 strata. In ST S7, though, a mottled, disturbed stratum was evident throughout the vertical profile to the terminal depth of excavation at $70 \mathrm{cmbs}$.

With two exceptions, the remainder of the shovel tests were excavated to this terminal depth of excavation, 70 cmbs. The two exceptions encountered impenetrable limestone that precluded excavation to this prescribed level. Soils encountered in the negative shovel tests $(\mathrm{n}=22)$ were similar in color and texture to the natural strata present in ST R6. Inclusions varied, with slightly higher or lower densities of primarily limestone gravels encountered across the project area. None of the negative shovel tests exhibited evidence of significant subsurface disturbance similar to that encountered in ST S7.

Table 5-1. Artifact Recovery from Shovel Tests S7 and R6 at 41BX1570

\begin{tabular}{|c|c|c|l|l|c|}
\hline $\begin{array}{c}\text { Shovel } \\
\text { Test }\end{array}$ & Level & $\begin{array}{c}\text { Depth } \\
\text { (cmbs) }\end{array}$ & \multicolumn{1}{|c|}{ Class } & \multicolumn{1}{|c|}{ Description } & Count \\
\hline S7 & 1 & $0-10$ & Glass & Flat & 1 \\
\hline S7 & 2 & $10-20$ & Glass & Curved, clear & 5 \\
\hline S7 & 2 & $10-20$ & Glass & Curved, olive & 1 \\
\hline S7 & 2 & $10-20$ & Glass & Curved, amber & 5 \\
\hline S7 & 2 & $10-20$ & Metal & Nail, wire & 3 \\
\hline S7 & 2 & $10-20$ & Ceramic & Whiteware & 1 \\
\hline S7 & 3 & $20-30$ & Debitage & & 1 \\
\hline S7 & 3 & $20-30$ & Glass & Curved, amber & 1 \\
\hline S7 & 3 & $20-30$ & Glass & Curved, lt. green & 3 \\
\hline S7 & 3 & $20-30$ & Glass & Curved, clear & 3 \\
\hline S7 & 3 & $20-30$ & Metal & Indeterminate & 1 \\
\hline S7 & 7 & $60-70$ & Glass & Curved, amber & 2 \\
\hline S7 & 7 & $60-70$ & Debitage & & 1 \\
\hline S7 & 7 & $60-70$ & Burned Rock & Limestone & 1 \\
\hline R6 & 3 & $20-30$ & Burned Rock & Chert & 5 \\
\hline R6 & 3 & $20-30$ & Debitage & & 3 \\
\hline R6 & 4 & $30-40$ & Debitage & & 1 \\
\hline R6 & 5 & $40-50$ & Burned Rock & Chert & 6 \\
\hline R6 & 5 & $40-50$ & Burned Rock & Limestone & 8 \\
\hline R6 & 5 & $40-50$ & Debitage & & 1 \\
\hline R6 & 6 & $50-58$ & Burned Rock & Chert & 8 \\
\hline R6 & 6 & $50-58$ & Debitage & & 1 \\
\hline & & & & & \\
\hline
\end{tabular}




\section{Chapter 6: Summary}

This report has presented the results of the archaeological investigations for the proposed Seton Home development and expansion project. A total of 24 shovel tests was excavated across the project area. The extant, southern boundary of 41BX1570 was defined with the excavation of six shovel tests in the northern portion of the project area. Of these six shovel tests, two were positive for cultural material. No other significant cultural deposits or features were encountered during the pedestrian reconnaissance or shovel testing.

The landform atop which the campus sits is a remnant terrace of the San Antonio River. Based on the review of cartographic sources, it is possible that the river was at one time adjacent to this landform. The combination of proximity to potable water and situation atop a terrace landform comprised of well-drained loam and clay loam deposits would have made an attractive occupation site for prehistoric inhabitants. It is probable that this location for the adjacent Mission Concepción was equally attractive for Spanish Colonial settlers as well, although no Colonial-period remains were located during the fieldwork.

In conclusion, the current archaeological survey has defined the southern boundary of a prehistoric site (41BX1570) of unknown temporal affiliation. During previous (Mahoney 2003) and current analyses of the artifact assemblages recovered from this site, however, it is apparent that significant subsurface disturbance has compromised the stratigraphic integrity of the deposits associated with this prehistoric site. Additional shovel testing under this project failed to identify significant, in situ cultural deposits associated with 41BX1570. It is, therefore, the recommendation of the Center for Archaeological Research that this site is neither eligible for inclusion on the National Register of Historic Places nor listing as a State Archeological Landmark.

\section{Additional Considerations}

Under the Scope of Work for the current project, archaeological monitoring of a subsurface utility line is specified. Location of the line is proposed at or near the northern property boundary separating Seton Home and St. PJ's. Site 41BX1570 will be bisected by the utility line, regardless of alternative placement in the general vicinity. At the time of publication of this report, the utility line route had yet to be established. As such, this document serves to provide clearance for cultural resources only in the remainder of the project area. Accordingly, it is recommended that construction be allowed to proceed outside of this proposed northern utility corridor. A subsequent letter report will be produced that incorporates the results of the monitoring of the utility trench excavation once the corridor has been established. 


\section{References Cited}

Black, S. L.

1989 Central Texas Plateau Prairie. In From the Gulf Coast to the Rio Grande: Human Adaptation in Central, South and Lower Pecos Texas, by T. R. Hester, S. L. Black, D. G. Steele, B. W. Olive, A. A. Fox, K. J. Reinhard, and L. C. Bement, pp. 17-38. Research Series No. 33. Arkansas Archeological Survey, Fayetteville.

Blair, W. F.

1950 The Biotic Provinces of Texas. Texas Journal of Science 2(1):93-117.

Brown, K. M.

1987 Early Occupation at Berger Bluff, Goliad County, Texas. Current Research in the Pleistocene 4:3-5.

Brown, M. J., A. A. Fox, and B. A. Meissner

1994 Archaeological Testing for the Mission Road Realignment Project, Phase II, at Mission Concepción, San Antonio, Texas. Archaeological Survey Report, No. 222. Center for Archaeological Research, The University of Texas at San Antonio.

Campbell, T. N.

1976 Archaeological Investigations at the Morhiss Site, Victoria County, Texas, 1932-1940. In An Archaeological Survey of Coleto Creek, Victoria and Goliad Counties, Texas, by A. A. Fox and T. R. Hester, pp. 81-85. Archaeological Survey Report, No. 18. Center for Archaeological Research, The University of Texas at San Antonio.

Collins, M. B.

1995 Forty Years of Archeology in Texas. Bulletin of the Texas Archeological Society 66:361-400.

1998 Wilson-Leonard: An 11,000-year Archeological Record of Hunter-Gatherers in Central Texas. Studies in Archeology, Report No. 31. Texas Archeological Research Laboratory, The University of Texas at Austin; Archeology Studies Program, Report No. 10. Environmental Affairs Division, Texas Department of Transportation, Austin.

Fenneman, N.

1931 Physiography of the Western United States. McGraw Hill, New York.

Fox, A. A.

1988 Archaeological Excavations at Mission Concepción, Fall of 1986. Archaeological Survey Report, No. 172. Center for Archaeological Research, The University of Texas at San Antonio.

1989 Monitoring of Utility Trenches at Mission Concepción, San Antonio, Texas, 1988. Archaeological Survey Report, No. 180. Center for Archaeological Research, The University of Texas at San Antonio.

1992 Archaeological Investigation to Locate the Northwest Corner of Mission Concepción, San Antonio, Bexar County, Texas. Archaeological Survey Report, No. 212. Center for Archaeological Research, The University of Texas at San Antonio. 
Hall, G. D.

1981 Allens Creek: A Study in the Cultural Prehistory of the Brazos River Valley, Texas. Research Report 61. Texas Archeological Survey, The University of Texas at Austin.

1984 Archaeology of the Texas Central Coastal Plain. Unpublished manuscript on file, Center for Archaeological Research, The University of Texas at San Antonio.

Hall, G. D., T. R. Hester, and S. L. Black (editors)

1986 The Prehistoric Sites at Choke Canyon Reservoir, Southern Texas: Results of the Phase II Archaeological Investigations. Choke Canyon Series, No. 10. Center for Archaeological Research, The University of Texas at San Antonio.

Hester, T. R.

1978 Background to the Archaeology of Chaparrosa Ranch, Southern Texas. Volume I: Studies in the Archaeology of Chaparrosa Ranch. Special Report, No. 6. Center for Archaeological Research, The University of Texas at San Antonio.

1995 The Prehistory of South Texas. Bulletin of the Texas Archeological Society 66:427-459.

Hester, T. R., and T. C. Hill

1975 Some Aspects of Late Prehistoric and Protohistoric Archaeology in Southern Texas. Special Report, No. 1. Center for Archaeological Research, The University of Texas at San Antonio.

Ivey, J. E., and A. A. Fox

1999 Archaeological Investigations at Mission Concepción and Mission Parkway. Archaeological Survey Report, No. 114. Center for Archaeological Research, The University of Texas at San Antonio.

Kelly, R. L.

1983 Hunter-Gatherer Mobility Strategies. Journal of Anthropological Research 39:277-306.

Labadie, J. H.

1989 Archaeological and Historical Investigations for the Mission Road Realignment Project, San Antonio, Texas. Archaeological Survey Report, No. 173. Center for Archaeological Research, The University of Texas at San Antonio.

McGraw, A. J., and D. Knepper

1983 The East Chacon Project: 11,000 Years of Prehistory along the Upper Nueces River, Southern Texas. Archaeological Survey Report, No. 125. Center for Archaeological Research, The University of Texas at San Antonio.

Mahoney, R. B.

2003 Archaeological Survey for the Proposed St. Peter-St. Joseph Children's Home Expansion, City of San Antonio, Bexar County, Texas. Archaeological Survey Report, No. 342. Center for Archaeological Research, The University of Texas at San Antonio.

Meissner, B.A.

2001 Mission Concepción: Introduction. In Archaeological Investigations at Four San Antonio Missions: Mission Trails Underground Conversion Project, edited by C. L. Tennis, pp. 63-65. Archaeological Survey Report, No. 297. Center for Archaeological Research, The University of Texas at San Antonio. 
Perttula, T. K.

1997 Hunter-Gatherer Mortuary Practices. In Archaeology of the Rio Grande and Central Coastal Plains, Texas: A Planning Document, pp. 7.1-7.51, edited by S. A. Tomka, T. K. Perttula, and R. J. Hard. Archaeological Survey Report, No. 266 (Draft). Manuscript on file Center for Archaeological Research, The University of Texas at San Antonio.

Prewitt, E. R.

1981 Culture Chronology in Central Texas. Bulletin of the Texas Archeological Society 52:65-89.

1995 Distributions of Typed Projectile Points in Texas. Bulletin of the Texas Archeological Society 66:83-173.

Scurlock, D., and D. E. Fox

1977 An Archeological Investigation of Mission Concepción, San Antonio, Texas. Office of the State Archeologist, Texas Historical Commission, Austin.

Skelton, D. W.

1977 Archeological Investigations at the Fayette Power Project, Fayette County, Texas. Research Report 60. Texas Archeological Survey, The University of Texas at Austin.

Sollberger, J. B., and T. R. Hester

1972 The Strohacker Site: A Review of Pre-Archaic Manifestations in Texas. Plains Anthropologist 17(58):326-344.

Story, D. A.

1985 Adaptive Strategies of Archaic Cultures of the West Gulf Coastal Plain. In Prehistoric Food Production in North America, edited by R. I. Ford, pp. 19-56. Anthropological Papers No. 75. Museum of Anthropology, University of Michigan, Ann Arbor.

Tankersley, K. B., and B. L. Isaac

1990 Early Paleoindian Economies of North America. JAI Press, Greenwich, Conn.

Taylor, A. J., and C. L. Highley

1995 Archaeological Investigations at the Loma Sandia Site (41LK28): A Prehistoric Campsite in Live Oak County, Texas, 2 volumes. Studies in Archeology No. 20. Texas Archeological Research Laboratory, The University of Texas at Austin.

Taylor, F. B., R. B. Hailey, and D. L. Richmond

1991 Soil Survey of Bexar County, Texas. United States Department of Agriculture, Soil Conservation Service, Washington, D.C.

Tomka, S. A., T. K. Perttula, and R. J. Hard

1997 Archaeology of the Rio Grande and Central Coastal Plains, Texas: A Planning Document. Archaeological Survey Report, No. 266 (Draft). Manuscript on file Center for Archaeological Research, The University of Texas at San Antonio.

Vierra, B. J.

1998 41MV120: A Stratified Late Archaic Site in Maverick County, Texas. Archaeological Survey Report, No. 251. Center for Archaeological Research, The University of Texas at San Antonio; Archeology Studies Program, Report No. 7. Environmental Affairs Division, Texas Department of Transportation, Austin. 
